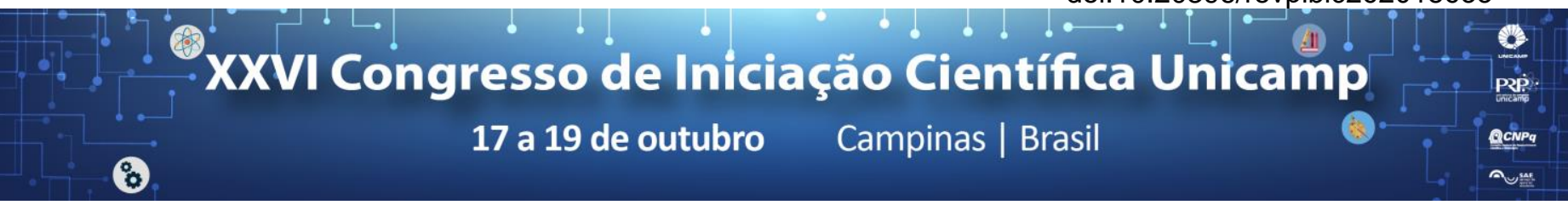

\title{
Citotoxicidade e potencial remineralizador de um gel clareador experimental contendo nanopartículas de biovidro
}

\section{Isabella Martin*, Gabriel Flores Abuna, Paulo Ferreira Campos, Daylana Pacheco, Vanessa Cavalli Gobbo}

\section{Resumo}

O presente estudo teve como objetivo avaliar as propriedades físicas do esmalte clareado com agentes clareadores experimentais com a adição de nanopartículas de biovidro, e a penetração, eficácia e citotoxidade do gel. Blocos de esmalte foram submetidos ao clareamento com $(n=10)$ : Controle - $0 \%$ de biovidro; $5 \%$ de biovidro; $10 \%$ de biovidro e $15 \%$ de biovidro, adicionados à uma matriz de peróxido de hidrogênio $12 \%$. Avaliou-se a alteração da microdureza Knoop, rugosidade média e alteração de cor $(\Delta \mathrm{E})$ antes, $24 \mathrm{~h}, 7,14$ e 21 dias após a aplicação do gel. A citotoxidade e a penetração dos géis experimentais também foi determinada e os dados estatisticamente analisados.

\section{Palavras-chave:}

Remineralização dentária; Clareamento Dental; Cor.

\section{Introdução}

O clareamento pode provocar alterações no conteúdo mineral do esmalte, devido à oxidação e baixo $\mathrm{pH}$ de alguns agentes. Desta forma, a formulação de um agente clareador que contenha aditivos capazes de reverter a perda mineral do esmalte, torna-se necessária.

\section{Resultados e Discussão}

Incisivos bovinos (40) foram avaliados quanto à dureza, rugosidade e $\Delta E$ do esmalte. Em seguida, foram submetidos a uma sessão de clareamento durante três tempos de 15 minutos, com peróxido de hidrogênio $12 \%$, com adição de $(n=10) \quad 0 \%, 5 \%, 10 \%$ e $15 \%$ de nanopartículas de biovidro, respectivamente. Novas leituras foram realizadas após 24 horas, 7 dias, 14 dias e 21 dias do término do clareamento. A penetração do gel no esmalte foi observada em microscopia confocal de varredura a laser. Os dados foram estatisticamente avaliados (Análise multivariada, MANOVA) com nível de significância de $5 \%$.

Figura 1. Micropermeabilidade por microscopia de varredura confocal por laser.

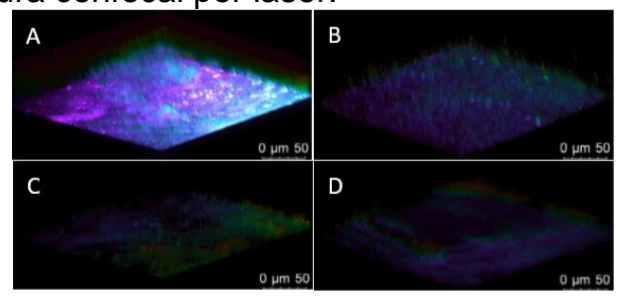

Figura 2. Alteração de cor do esmalte submetido aos agentes clareadores, avaliados 24 h, 7 d, 14 e 21 dias em relação ao baseline.

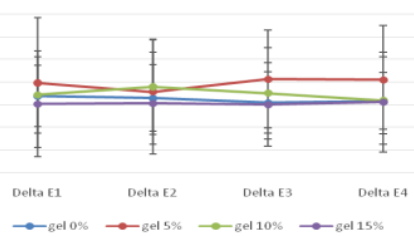

Figura 3. Microdureza (KHN) do esmalte submetido aos agentes clareadores, avaliados 24 h, 7 d, 14 e 21 dias em relação ao baseline.

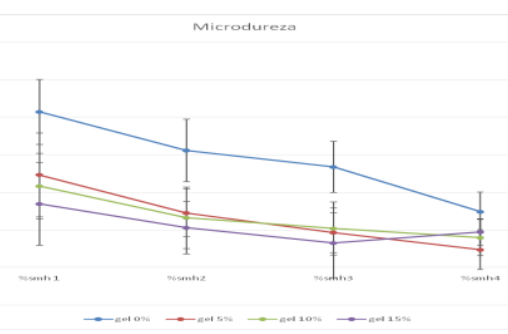

Figura 4. Rugosidade ( $\mathrm{Ra}, \mu \mathrm{m})$ do esmalte submetido aos agentes clareadores, avaliados 24 h, 7 d, 14 e 21 dias em relação ao baseline.

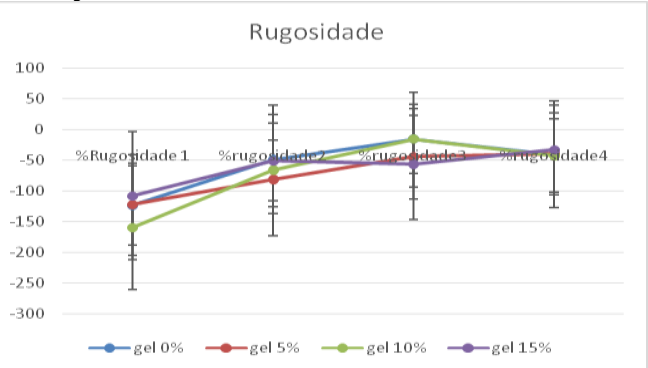

Figura 5. Citotoxicidade (\% de viabilidade celular) de acordo com diferentes concentrações do gel clareador

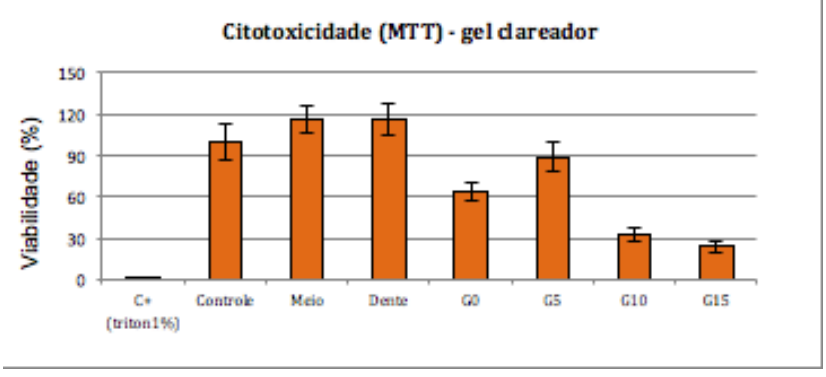

\section{Conclusões}

Houve aumento da rugosidade do esmalte clareado e diminuição da microdureza, porém, o gel clareador com $5 \%$ de nano biovidro apresentou menores alterações físicas e a maior alteração de cor entre os grupos clareados, além de apresentar a maior viabilidade celular entre as concentrações.

\section{Agradecimentos}

Ao CNPq e ao Centro de Microscopia da FOP-Unicamp. 